\title{
Study of the Influence of Key Process Parameters on Furfural Production
}

\author{
Ljudmila Fele Žilnik, ${ }^{* 1}$ Viktor Grilc, ${ }^{1}$ Ivan Mirt ${ }^{2}$ and Željko Cerovečki \\ ${ }^{1}$ National Institute of Chemistry, Hajdrihova 19, SI-1000 Ljubljana, \\ ${ }^{2}$ Tanin Sevnica d.d., Hermanova 1, SI-8290 Sevnica \\ * Corresponding author: E-mail: ljudmila.fele@ ki.si \\ Tel: +38614760 220; fax: +38614760300.
}

Received: 05-01-2016

\begin{abstract}
The present work reports the influence of key process variables on the furfural formation from leached chestnut-wood chips in a pressurized reactor. Effect of temperature, pressure, type and concentration of the catalyst solution, the steam flow rate or stripping module, the moisture content of the wood particles and geometric characteristics such as size and type of the reactor, particle size and bed height were considered systematically. One stage process was only taken into consideration. Lab-scale and pilot-scale studies were performed. The results of the non-catalysed laboratory experiments were compared with an actual non-catalysed (auto-catalysed) industrial process and with experiments on the pilot scale, the latter with $28 \%$ higher furfural yield compared to the others. Application of sulphuric acid as catalyst, in an amount of $0.03-0.05 \mathrm{~g}\left(\mathrm{H}_{2} \mathrm{SO}_{4} 100 \%\right) / \mathrm{g}$ d.m. (dry material), enables a higher production of furfural at lower temperature and pressure of steam in a shorter reaction time. Pilot scale catalysed experiments have revealed very good performance for furfural formation under less severe operating conditions, with a maximum furfural yield as much as $88 \%$ of the theoretical value.
\end{abstract}

Keywords: Furfural production, chestnut woodchips, process variables, acid catalysed process

\section{Introduction}

Interest in the production of bio-chemicals and biofuels from renewable resources has vastly increased in the last decade, mainly as a result of the limited availability of petroleum reserves and to reach the goals of Paris 2015 Agreement. Biomass residues represent a potential source for production of chemicals such as alcohols, sugars, phenolic fractions, furfural, lower organic acids, etc. There is an ongoing challenge to develop economically-efficient and environmentally-benign technologies to transform lignocellulosic biomass into fuels ${ }^{1}$ and chemicals. ${ }^{2}$ Furfural, derived from hemicelluloses that are composed mainly of pentoses (C5 carbohydrates), is an extremely important intermediate for high value-added products, especially for the synthesis of furan derivatives, solvents for a broad range of applications, fungicides, insecticides, resins etc. Recently, an increased interest has arisen to upgrade furfural to furan-based biofuels or fuel additives, chemical intermediates and bio-solvents that are less toxic; correspondingly the value of furfural has increased.
Furfural is almost exclusively produced by hydrolysis of pentosanes from plant residues to pentoses, followed by the dehydration reaction to furfural, since no competitive commercial synthetic route exists. ${ }^{3-4}$ The mechanism of the furfural formation from the lignocellulosic material is relatively well defined, but very little information about kinetics of these heterogeneous reactions is known. The majority of the authors considered the hydrolysis reaction of the hemicellulose with respect to the cleavage mechanism of the glycosides bond as pseudo-homogeneous reaction. Pseudo kinetic model was proposed, mainly as a result of non-uniform polymer characteristics of hemicellulose and partly unexplained parallel reactions and consecutive degradation reactions of furfural. Furfural is formed from pentosanes by two consecutive reactions, namely hydrolysis of the pentosane-chain into pentoses and their dehydration via intermediates to furfural. ${ }^{5}$ Both reactions take place in solid and liquid phase, but the mass transfer occurs also in the vapor phase. Abatzoglou et al. ${ }^{6}$ in their work on acid catalysed hydrolysis of sawdust, suspended in dilute solution of mineral acid in a continuous plug flow reactor, sug- 
gested the use of a simple empirical pseudo-kinetic model, without taking into account the formation and disappearance of intermediates. The cleavage of the glycoside bond and sugar formation was described by several authors ${ }^{7-8}$ and discussed by Agirrezabal-Telleria et al. ${ }^{9}$ and has been carried out in several subsequent steps, using steam or dilute acid pretreatment. The hydrolysis of pentosane to pentose starts with protonation of the ether oxygen link to form a trivalent oxygen, followed by a cleavage of the oxygen bond to give the carbonium ion on one side and a hydroxyl group on the other side, reaction of the carbonium ion with water, liberation of $\mathrm{H}^{+}$ion and the $\mathrm{OH}$-group formation. Antal et al. ${ }^{10}$ examined the furfural formation mechanism from D-xylose in water with and without catalyst. Two alternative hypotheses were studied; the first one suggested the consecutive reactions via intermediates with open rings and the other one the acid catalysed consecutive reactions with intermediate 2, 5-anhydride. The latter model was more consistent with experimental data. The mechanism of pentose cyclodehydration to furfural by two subsequent 1 , 2-eliminations and 1,4-elimination was presented ${ }^{8}$ and discussed as the main mechanism reported for Broensted acid catalysed cyclodehydration process.

A very recent review of the literature ${ }^{9}$ shows increased activities in studying the dehydration reactions of sugars promoted by (homogeneous) acid catalysts such as formic, acetic, sulphuric and phosphoric acid, using the combined mineral acids and salts as catalysts, as well as by heterogeneous acid catalysts. Among homogeneous catalysts sulphuric acid is the most commonly used in the industrial production of furfural. ${ }^{11-12}$ Recent research on furfural formation and production, searching for novel catalytic systems based on Lewis acid sites ${ }^{13}$ has indicated the difference in the reaction pathways of Broensted acid catalysed xylose dehydration to Lewis/Broensted acid catalysed process. The authors suggested that using the combined Lewis and Broensted acids, xylose isomerization (Lewis acid catalysed) to xylulose and subsequent dehydration (Broensted acid catalysed) dominates over the direct con- version of xylose to furfural, catalysed only by the Broensted acid. The synergistic effect between Lewis acid catalysts and concentrated carboxylic acid (weak Broensted acidity) solutions towards the furfural formation from xylose was observed. ${ }^{14}$ According to recent studies the Lewis/Broensted acid site ratio directly affects the dehydration rate and the furfural yield. Lewis acid sites accelerate the xylose conversion rate as compared to Broensted sites, whereas the presence of Broensted site is required to achieve a significant furfural yield improvement.

The first reaction step of furfural formation from pentosanes is therefore auto-catalysed hydrolysis towards mono-sugar production, which proceeds rapidly, while the second step, namely the dehydration, is much slower and therefore a considerable loss of furfural occurs through side reactions, such as degradation and condensation. As a consequence, much lower yield of furfural is achieved in its production process as compared to theoretically attainable one. The average pentosan contents of some raw materials, theoretical furfural yields and yields in industrial processes are given in Table 1. It can be noticed that only around 55-60\% of the potential furfural yield, determined according to AOAC method, can be exploited in noncatalysed industrial processes, which accounts for around $30 \%$ of available pentosans in the raw material. Stoichometricaly, following both reactions, ${ }^{9}$ the theoretical furfural weight-basis yield from pentosan is $72.7 \%$ and $64 \%$ from pentose. The dehydration reaction, when catalysed by other catalyst than acetic acid, may be appropriately tuned to improve furfural yield and make the process more efficient. ${ }^{15}$ The prompt removal of furfural from the reactor is of crucial importance as well, therefore a stripping agent such as steam or nitrogen is used, or an appropriate extraction process can be employed.

\section{1. Aim of the Work}

In the chemical processing plant at Tanin Sevnica chemical company http://www.tanin.si/ (Figure 1), furfur-

Table 1. Pentosan content of raw materials, theoretical furfural yields and yields in industrial processes. ${ }^{16,3}$

\begin{tabular}{lccc}
\hline Raw materials & $\begin{array}{c}\text { Pentosan content } \\
\text { \% }\end{array}$ & $\begin{array}{c}\text { Theoretical* } \\
\text { furfural yield \% }\end{array}$ & $\begin{array}{c}\text { Furfural yields in } \\
\text { industrial processes \% }\end{array}$ \\
\hline Corncobs & $30-32$ & 23.4 & 10 \\
Oats husks & 40 & 22.4 & 10 \\
Cotton husks & $23-28$ & 18.6 & $8-9$ \\
Bagasse & $25-27$ & 17.4 & $8-9$ \\
Birch wood $^{+}$ & 25 & 18.0 & $7-8$ \\
Chestnut wood $^{+}$ & 16.7 & 11.2 & $5-6$ \\
Oak wood $^{+}$ & $20-21$ & 11.7 & $5-6$ \\
Olive cake $_{\text {Rice husk }}$ & $21-23$ & 16.6 & $5-6$ \\
Sunflower hull & $16-18$ & - & 6 \\
\hline
\end{tabular}

*-according to Association of Agricultural Chemists (AOAC) ${ }^{+}-$leached wood chips after tannin extraction 
al, acetic acid and methanol are produced from leached chestnut wood chips through the hydrothermal auto-catalysed process using steam as a hydrolyzing, stripping and separating agent. From the raw material point of view, the process operates in a batch manner, with two reactors in sequence. About $3500 \mathrm{~kg}_{\text {drymatter }} / \mathrm{h}$ of leached wood chips enters the furfural production plant shown in Figure 1.

In the present work, the research aiming at hydrothermal process optimization of the furfural production was carried out, with the main purpose to systematically determine and examine closely the key process (thermodynamic, operating) parameters that influence the furfural yield, primarily on the laboratory scale. The findings from bench-scale experiments were subsequently used as a starting point to plan the development work on the pilot plant and semi-industrial scale production plant. Non-catalysed and catalysed processes were considered.

\section{Materials and Methods}

For this study a batch of leached chestnut wood chips was received, sampled from the material employed in the industrial process, with the pentosan content of $17-19 \%_{\text {d.m. }}$ (on the dry basis) and average moisture content between 40 and $45 \%$. The material was stored in the cold room at temperature of $5{ }^{\circ} \mathrm{C}$, while smaller amounts of the material for daily needs were held in the fridge. Before each experiment, the characterization of the raw material was performed, namely the particle size distribution, bed bulk density and average moisture content of the material. The measured bed bulk density varied between $0.26 \mathrm{~g} / \mathrm{mL}$ up to $0.34 \mathrm{~g} / \mathrm{mL}$. In our experiments, the leached chestnut wood chips with two different moisture contents of approx. $30 \%$ and $43 \%$ were used. The major part ( $80 \mathrm{wt} . \%$ ) of the particles were of the size between $2.0 \mathrm{~mm}$ and $11.2 \mathrm{~mm}$. Due to clogging problems in preliminary experiments, a decision was made to use sieved material without fine fraction (particles below $2 \mathrm{~mm}$ ) in our catalytic experiments. As a catalyst, sulphuric acid of different concentrations $(3.7 \%, 38.5 \%$ and $90 \%)$ in an amount of $0.03-0.05 \mathrm{~g} \mathrm{H}_{2} \mathrm{SO}_{4} / \mathrm{g}$ d.m. (dry material) was applied. Catalyst application on the particles was made by wet impregnation and spraying methods, the former when dilute sulphuric acid was used as a catalyst. Sulphuric acid p.a. (concentration of $95-97 \%$, density of $1.84 \mathrm{~kg} / \mathrm{L}$ ) was diluted in demineralized water to prepare solutions of different concentrations. Demineralized water was utilized to produce process steam for the reaction.

\section{1. Analytical Methods}

Weighing of leached chestnut wood chips and cellolignin was carried out using two laboratory balances of

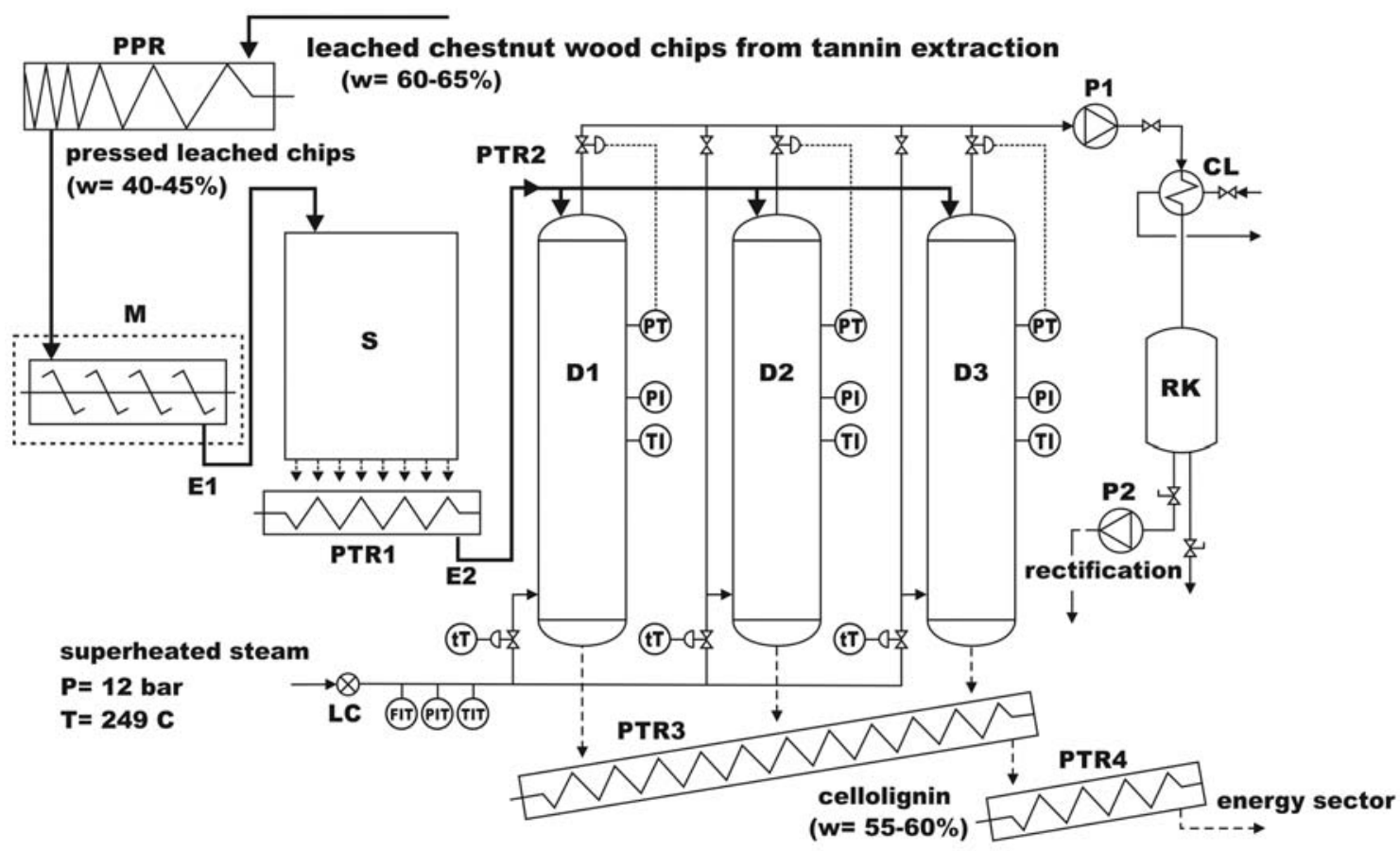

Figure 1. Process scheme of the industrial non-catalysed furfural production plant.

Legend: PPR - press, M - mixer for catalyst application onto the wood particles (in preparation), S - silo, E1 and E2 - elevators, PTR1, PTR2, PTR3 and PTR4 - conveyors, D1, D2, D3 - reaction vessels, P1, P2 - pumps, CL - cooling line, RK - reservoir for reaction condensate, LC steam condensate remover, FIT - steam flow rate indicator and transmitter, PI - pressure indicator, PIT - pressure indicator and transmitter, PT pressure transmitter, $\mathrm{tT}$ - time transmitter, TI - temperature indicator, TIT - temperature indicator and transmitter. 
appropriate accuracies. Analytical balance Mettler ${ }^{\circledR}$ AT 261 with an accuracy of $\pm 0.1 / 0.01 \mathrm{mg}$ and maximum load of $205 \mathrm{~g}$ was employed for analytical purposes.

Before each experiment, the particle size analysis was performed on a Fritch ${ }^{\circledR}$ Pulverisette model 301.0 using standard sieves Retsch ${ }^{\circledR}$ of sizes 16.00, 11.20, 6.30, $3.15,2.00$ and $1.00 \mathrm{~mm}$, according to the standard DINISO 3310/1. $100 \mathrm{~g}$ of homogeneously mixed material was taken for the particle size analysis. After 10 min of material shaking, the fractions were weighed and the moisture content of each fraction was determined by means of the moisture analyzer Mettler ${ }^{\circledR}$ PM 460 with an accuracy of $\pm 0.01 \mathrm{~g}$ for mass and of $\pm 0.01 \%$ for moisture and maximum load of $410 \mathrm{~g}$. Average weight percent of the fraction size and their moisture content were calculated. In every experiment, the characterization of each stream of the wood material (chips), entering or leaving the process (cellolignin residue), was carried out. Average moisture content of the material was determined also after the catalyst application on the leached chestnut wood particles.

Gas chromatography was used to analyze the composition of the outlet flow from the reactor. The stream from the reactor consisted of furfural, ethanoic acid, methanol and 5-methyl-furfural dissolved in water. Analysis were performed on GC Carlo Erba ${ }^{\circledR}$ model 8130, equipped with flame ionization detector, using HP-FFAP capillary column of the length of $50 \mathrm{~m}, 0.32 \mathrm{~mm}$ ID with $0.52 \mu \mathrm{m}$ film thickness to achieve the separation. The column was filled with Carbowax $20 \mathrm{M}$, covered with polyethylene glycol polar phase modified by nitrotherephtalic acid. Oven temperature was held at $150{ }^{\circ} \mathrm{C}$, the injector and detector temperatures were $220{ }^{\circ} \mathrm{C}$ and $200{ }^{\circ} \mathrm{C}$, respectively. Hydrogen served as a carrier gas with a flowrate of $1.5 \mathrm{~mL} / \mathrm{min}$. For the quantification of compounds in the samples an internal standard (IS) method was used, with propionic acid as IS. The samples were filtered through $0.25 \mu \mathrm{m}$ filter prior the injection.

When catalysed experiments were performed, the amount of acid applied on the leached wood particles was determined and controlled by potentiometric titration on pH-meter ISKRA ${ }^{\circledR}$ MA 5740.

\section{2. Furfural Formation}

Series of experiments, non-catalysed and catalysed, were carried out first on the laboratory scale and later on the pilot scale to examine the influence of key parameters such as: temperature, pressure, type of catalyst solution used and its concentration, the steam flow rate (measured through the amount of its cumulative condensate, represented by the stripping module $S_{m}\left(\mathrm{ml} / g_{\text {dry.matter }} \cdot h\right)$ ), the moisture content of the leached chestnut-wood particles and geometric characteristics (size and type of the reactor, mean particle size, bed height). One stage process was considered, meaning that reactions, hydrolysis and dehydration are taking place in the same apparatus.

\section{2. 1. Laboratory Experimental Setup and Procedure}

Experiments were first carried out on the laboratory apparatus, shown in Figure 2, consisted of the pressure reactor Ernst Haage ${ }^{\circledR}$ type 1220 , constructed of $\mathrm{Cr}-\mathrm{Ni}-\mathrm{Mo}$ steel, of $2 \mathrm{~L}$ volume $(\mathrm{D}=10 \mathrm{~cm}, \mathrm{H}=27 \mathrm{~cm})$, with operating temperature up to $350{ }^{\circ} \mathrm{C}$ and pressure up to 325 bars. The reactor was heated by an electric heating coil mounted in a double insulation jacket of the reactor. The temperature was measured in the middle of the reactor by thermocouple wire $\mathrm{Fe}-\mathrm{CuNi}$ (Constantan) and controlled by temperature controller. Additional thermocouple Dalmacija ${ }^{\circledR}(\mathrm{NiCr}-\mathrm{Ni})$ with the operating range between $-65.0{ }^{\circ} \mathrm{C}$ and $199.0^{\circ} \mathrm{C}$ and accuracy of $\pm 0.1{ }^{\circ} \mathrm{C}$ was inserted in the reactor to measure the temperature. The pressure was measured by Bourdon tube pressure gauge with the measuring range of $0-16$ bar and accuracy of \pm 0.1 bar. Glass wool served as thermo-insulation of the reactor. Steam was produced in a stainless steel autoclave Andreas Hofer ${ }^{\circledR}$ with the following characteristics: $\mathrm{V}_{\text {net }}=50 \mathrm{~L}, \mathrm{D}=$ $30 \mathrm{~cm}, \mathrm{H}=75 \mathrm{~cm}, \mathrm{~T}_{\max }=350{ }^{\circ} \mathrm{C}, \mathrm{P}_{\max }=100 \mathrm{bar}, \mathrm{P}_{\text {heating }}=$ $18 \mathrm{~kW}_{\mathrm{el}}$. Steam was fed to the reactor on a side of a reactor cover through the feeding line, which led to the lower one third of the reactor. To prevent the condensation of the steam in the line between the steam chamber and the reactor, electrical heating mantle was employed. Two needle valves were used to control the pressure in the reactor and steam flow at the exit of the reactor. The outlet flow was condensed and measured.

Non-catalysed experiments were carried out to find out which parameters are playing the most important role

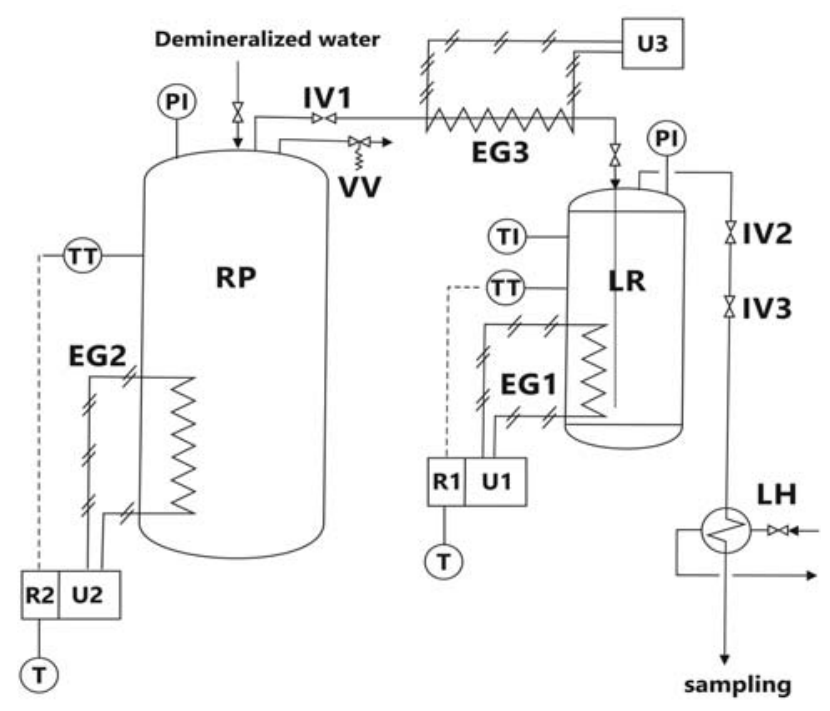

Figure 2. Scheme of the laboratory apparatus used for hydrothermal processing of leached chestnut-wood chips.

Legend: LR- reactor Ernst Haage 1220, RP - steam producer, LH cooler, IV1, IV2, IV3- needle valves, VV - safety valve, EG1, EG2, EG3 - electric heater, U1, U2, U3 - switched-mode power supply, $\mathrm{R} 1, \mathrm{R} 2$ - temperature controller, PI - pressure indicator, TI - temperature indicator, TT - temperature transmitter, T - temperature display. 
in the hydrothermal process and to compare the process conditions and furfural yields with the actual industrial process data from the company Tanin d.d., in spite of different geometry of the reactors.

The reactor was loaded with $550 \mathrm{~g}$ of leached chestnut wood chips, regardless of the moisture content. A sample of the leached wood chips was taken for particle fraction size analysis and average moisture content determination. In non-catalysed experiments leached chestnut wood chips with both initial moisture contents (31\% and $43 \%$ ) were treated. In catalysed process only leached chestnut wood chips with average moisture content of $43 \%$ and without particles size fraction below 2.0 $\mathrm{mm}$ were used. The reactor was sealed and preheated by an electric heater up to $100{ }^{\circ} \mathrm{C}$. The set temperature was reached in 13-20 minutes. Steam was introduced into the reactor with appropriate temperature and pressure and as soon as the operating $\mathrm{T}$ and $\mathrm{P}$ were reached in the reactor, the steam flow through the reactor was set to attain a pre-selected stripping module $\mathrm{S}_{\mathrm{m}}$ (rate of stream load), defined as the volume of the outlet condensate flow $(\mathrm{mL})$ per mass unit of dry wood in the reactor $(\mathrm{g})$ in unit of time (h). The time to reach the operating temperature in the reactor was recorded and denoted as the beginning of the process $\left(t_{o}\right)$. Non-catalysed experiments were carried out at temperatures between $180{ }^{\circ} \mathrm{C}$ and $190{ }^{\circ} \mathrm{C}$, at pressures between $9-12 \mathrm{bar}$, initial liquid/solid $(\mathrm{L} / \mathrm{S})$ ratios of 0.39 and $0.76 \mathrm{~g} / \mathrm{g}$ and stripping module between 1.0 and $1.3 \mathrm{~mL} / \mathrm{g}_{\text {d.m. }}$ h. In catalysed process, lower temperatures and pressures were applied, but higher initial L/S ratio between 1.5 and $1.8 \mathrm{~g} / \mathrm{g}$ and higher stripping module, in the range between 1.3 and 4.0 $\mathrm{mL} / \mathrm{g}_{\mathrm{d} . \mathrm{m}} \mathrm{h}$. Approximate the same load of the catalyst of different concentrations on the dry material was applied in all catalysed experiments.

The duration of non-catalysed and catalysed process was $120 \mathrm{~min}$ and $100 \mathrm{~min}$, respectively. Experiments at each of the process conditions were performed at least in triplicates. The first sample of the condensed outlet flow was taken 45 seconds after $t_{o}$, afterwards the sampling was carried out in intervals of $10 \mathrm{~min}$, and only at the beginning of catalysed experiments 5 min interval was chosen. The samples were cooled down to room temperature and prepared for GC analysis.

\section{2. 2. Pilot Scale Setup and Procedure}

Based on the findings from the laboratory experiments, the pilot reactor of a column type was build up, with an effective volume of $10 \mathrm{~L}, 88 \mathrm{~mm}$ of diameter and $2 \mathrm{~m}$ of height. The reactor was heated by steam, which entered a double insulation jacket of the reactor. The reactor was designed in such a way, that both ends could be opened. The raw material (leached chestnut wood chips) entered the top of the reactor and formed a fixed bed, while the steam was introduced through a perforated distributor, mounted in the reactor at the bottom part. The valve for steam condensate at the bottom was slightly opened during the experimental run. The filter plate at the top of the bed prevented the particles to leave the reactor together with steam. The outlet steam flow from the top of the reactor entered a separator, where fine dusty particles were removed, followed by condensation in a heat exchanger and collected in a graduated vessel. The samples were taken every $10 \mathrm{~min}$ for GC analysis.

\section{Results and Discussion}

\section{1. Effect of Temperature, Pressure, Stripping Module and Moisture Content in Non-catalysed Lab-scale Experiments}

A series of non-catalysed experiments were performed at two temperatures and pressures, using the particles with initial average moisture contents of $31 \%$ and $43 \%$ and by a variation of stripping module $\mathrm{S}_{\mathrm{m}}$. The operating conditions and results of most representative non-catalysed laboratory experiments are presented in Table 2.

Maximum concentration of furfural in the product stream was achieved 30-40 min after $\mathrm{t}_{0}$. It was found out that the initial moisture content of the particles in the concentration range studied did not have a significant effect on furfural yield of the process. Some differences in the dynamics of the furfural formation were noticed, but they could not be ascribed to the influence of the moisture content. The most important process parameters are temperature, pressure and stripping module. By lowering the tem-

Table 2. Conditions and results of the non-catalysed laboratory experiments of leached chestnut wood chips in one-stage process. ${ }^{16}$

\begin{tabular}{|c|c|c|c|c|c|c|c|c|c|}
\hline $\mathbf{t}_{\text {preheat }} \min$ & $\mathbf{m}_{\text {d.m. }} \mathbf{g}$ & $\mathbf{w}_{\mathrm{m}, \mathrm{p}} \%$ & L/S g/g & $\mathrm{w}_{\mathrm{m}, \mathrm{c}} \%$ & $\mathbf{T}{ }^{\circ} \mathbf{C}$ & P bar & $\mathrm{S}_{\mathrm{m}} \mathrm{mL} / \mathrm{g} . \mathbf{h}$ & $\mathrm{C}_{\mathrm{f}}^{\max \%}$ & $\eta_{f} \%$ \\
\hline 13 & 383.9 & 30.2 & 0.43 & 50.7 & 190.1 & 11.6 & 1.28 & 3.77 & 5.2 \\
\hline 15 & 396.0 & 28.0 & 0.39 & 40.8 & 181.1 & 8.8 & 1.24 & 2.67 & 3.7 \\
\hline 18 & 396.0 & 28.0 & 0.39 & 28.0 & 190.6 & 11.8 & 0.94 & 3.74 & 4.1 \\
\hline 15 & 312.4 & 43.2 & 0.76 & 53.9 & 191.1 & 11.9 & 1.35 & 3.92 & 5.1 \\
\hline
\end{tabular}

$\mathrm{t}_{\text {preheat }}$ - preheating time, $\mathrm{m}_{\mathrm{d} . \mathrm{m} .}$ - mass of dry material, $\mathrm{w}_{\mathrm{m}, \mathrm{p}}$ - average moisture content of the particles entering the process, $\mathrm{L} / \mathrm{S}-$ liquid to solid ratio, $w_{m, c}$ - average moisture content of cellolignin residue, $S_{m}$ - stripping module, $C_{f}{ }^{\text {max }}$ - maximum concentration of furfural in the outlet flow, $\eta_{\mathrm{f}}$ - furfural yield on the dry basis 
perature from $190{ }^{\circ} \mathrm{C}$ to $180^{\circ} \mathrm{C}$ and pressure from 12 bar to $9 \mathrm{bar}$, using the same stripping module, the furfural yield has decreased for about $30 \%$ (see Table 2).

In Figure 3a, the concentrations of furfural, ethanoic acid, methanol and 5-methyl furfural in the outlet stream from the reactor during non-catalysed experimental run on wood particles having $31.3 \%$ of moisture at $190{ }^{\circ} \mathrm{C}$, 11.6 bar and stripping module of $1.3 \mathrm{~mL} / \mathrm{g} . \mathrm{h}$ are depicted. Furfural reached its maximum concentration in $40 \mathrm{~min}$ of hydrothermal process, at the same time the concentration of ethanoic acid increased from $0.5 \%$ up to $2 \%$, in some experiments even up to $2.5 \%$ with its maximum concentration at the time near furfural maximum. The most volatile component methanol reached peak concentration of about $1 \%$ at the beginning, after that its concentration was decreasing. The concentration of byproduct 5-methyl furfural was quite low during the run, with the concentration between $0.1 \%$ and $0.2 \%$.

Using lower stripping module (e.g. $0.94 \mathrm{~mL} / \mathrm{g} . \mathrm{h}$ ), i.e. at lower linear velocity of the steam passing through the bed of leached chestnut wood chips, the furfural yield was only around $3-4 \%$ on the dry material, which means that we have lost the furfural due to side reactions taking place in the reactor.

The results from the laboratory experiments agreed fairly well with the actual non-catalysed industrial process.

\section{2. Effect of Catalyst Concentration, $T, P$ and Stripping Module in Catalysed Lab-scale Experiments}

In the catalysed experiments, leached chestnut wood chips with an average moisture content of $43 \%$ without particle fraction size below $2.0 \mathrm{~mm}$ were used in order to avoid the issues connected with uniform distribution of sulphuric acid, which served as a catalyst. The acid applied to fine particles might also cause the destruction of cellolignin and problems with stuffed valves at the exit of the reactor. An amount of the catalyst regardless its concentration was always in the range 0.03-0.05 $\mathrm{g} \mathrm{H}_{2} \mathrm{SO}_{4}$ /g d.m. (dry material). The effect of catalyst concentration, temperature, pressure and strip- ping module on the furfural formation from pentosans and on furfural yield was studied.

The operating conditions and results of most representative catalysed laboratory experiments with dilute (3.7\%) sulphuric acid are presented in Table 3. The catalyst in an amount of $0.03 \mathrm{~g} \mathrm{H}_{2} \mathrm{SO}_{4} / \mathrm{g} \mathrm{d}$.m. was applied by wet impregnation method, therefore the initial moisture content reached the value of $60 \%$ and the liquid/solid ratio in the reactor was around $1.5 \mathrm{~g} / \mathrm{g}$. The experiments were performed at two temperatures, namely at $170{ }^{\circ} \mathrm{C}$ and 180 ${ }^{\circ} \mathrm{C}$ and at various stripping modules (1.3, 2 and $3 \mathrm{~mL} / \mathrm{g}$.h). Preheating time from $100^{\circ} \mathrm{C}$ up to the operating temperature was found to be very important, and it should not last too long, otherwise lower furfural yield due to side reactions is inevitable.

The composition of the outlet flow from the reactor and the furfural yield achieved in the catalysed process for one run by dilute sulphuric acid is depicted in Figure $3 b$. The catalyst influenced the dynamics of the furfural formation; higher initial furfural concentration and its maximum concentration in 10-20 min after $t_{o}$ were noticed. Higher stripping module enhanced the removal of furfural from the surface of the wood particles to the vapor phase and minimized the possibility for side reactions of furfural, such as degradation and condensation.

Lower temperature $\left(170{ }^{\circ} \mathrm{C}\right)$ is more favorable for furfural production compared to higher temperature (180 $\left.{ }^{\circ} \mathrm{C}\right)$ at low stripping module $(1.3 \mathrm{~mL} / \mathrm{g} . \mathrm{h})$ due to lower extent of furfural side reactions. Lower pressure enables an enhanced diffusion of the reaction products such as furfural into the bulk steam phase. At higher steam flow rate, temperature in the range studied, did not influence the furfural yield significantly. Comparing the results with noncatalysed one, it can be noticed that dilute sulphuric acid enhanced the furfural formation at lower temperature and pressure, such as $170{ }^{\circ} \mathrm{C}$ and 7 bars. An increase of up to $45 \%$ in furfural yield was recorded when catalysed experiment instead of non-catalysed was performed at $180{ }^{\circ} \mathrm{C}$ and 8.5 bar at similar stripping module $(1.3 \mathrm{~mL} / \mathrm{g} . \mathrm{h})$. More pronounced effect on furfural yield can be reached by increasing the stripping module, as shown in Figure 4a. Linear dependency of furfural yield on stripping module is evident at $180{ }^{\circ} \mathrm{C}$ and 8.9 bars and from stripping mod-

Table 3. Conditions and results of the catalysed $\left(3.7 \% \mathrm{H}_{2} \mathrm{SO}_{4}\right.$ solution) laboratory experiments of leached chestnut wood chips in one-stage process. ${ }^{16}$

\begin{tabular}{|c|c|c|c|c|c|c|c|c|c|c|}
\hline $\mathbf{t}_{\text {preheat }} \min$ & $\mathbf{m}_{\text {d.m. }} \mathbf{g}$ & $\mathbf{w}_{\mathrm{m}, \mathrm{p}} \%$ & $\mathbf{w}_{\mathrm{m}, \mathrm{w}} \%$ & L/S g/g & $\mathbf{w}_{\mathrm{m}, \mathrm{c}} \%$ & $\mathbf{T}^{\circ} \mathbf{C}$ & P bar & $S_{m}$ mL/g.h & $\mathrm{C}_{\mathrm{f}}^{\max } \%$ & $\eta_{\mathrm{f}} \%$ \\
\hline 22 & 313.5 & 43.0 & 60.5 & 1.53 & 37.8 & 170.1 & 7.0 & 1.34 & 5.62 & 5.8 \\
\hline 22 & 313.5 & 43.0 & 60.8 & 1.55 & 24.7 & 178.6 & 8.5 & 1.35 & 5.93 & 5.4 \\
\hline 21 & 314.6 & 42.8 & 60.4 & 1.53 & 21.2 & 180.1 & 8.9 & 2.01 & 4.11 & 6.0 \\
\hline 19 & 314.0 & 42.9 & 60.3 & 1.52 & 41.2 & 169.7 & 6.7 & 2.99 & 3.41 & 8.1 \\
\hline
\end{tabular}

$\mathrm{t}_{\text {preheat }}$ - preheating time, $\mathrm{m}_{\mathrm{d.m} .}-$ mass of dry material, $\mathrm{w}_{\mathrm{m}, \mathrm{p}}-$ average moisture content of material before catalyst application, $\mathrm{w}_{\mathrm{m}, \mathrm{w}}-$ average moisture content of material after catalyst application, L/S- liquid to solid ratio, $\mathrm{w}_{\mathrm{m}, \mathrm{c}}-$ average moisture content of cellolignin residue, $\mathrm{S}_{\mathrm{m}}-$ stripping module, $C_{f}^{\max }-$ maximum concentration of furfural in the outlet flow, $\eta_{f}$ - furfural yield on the dry basis 

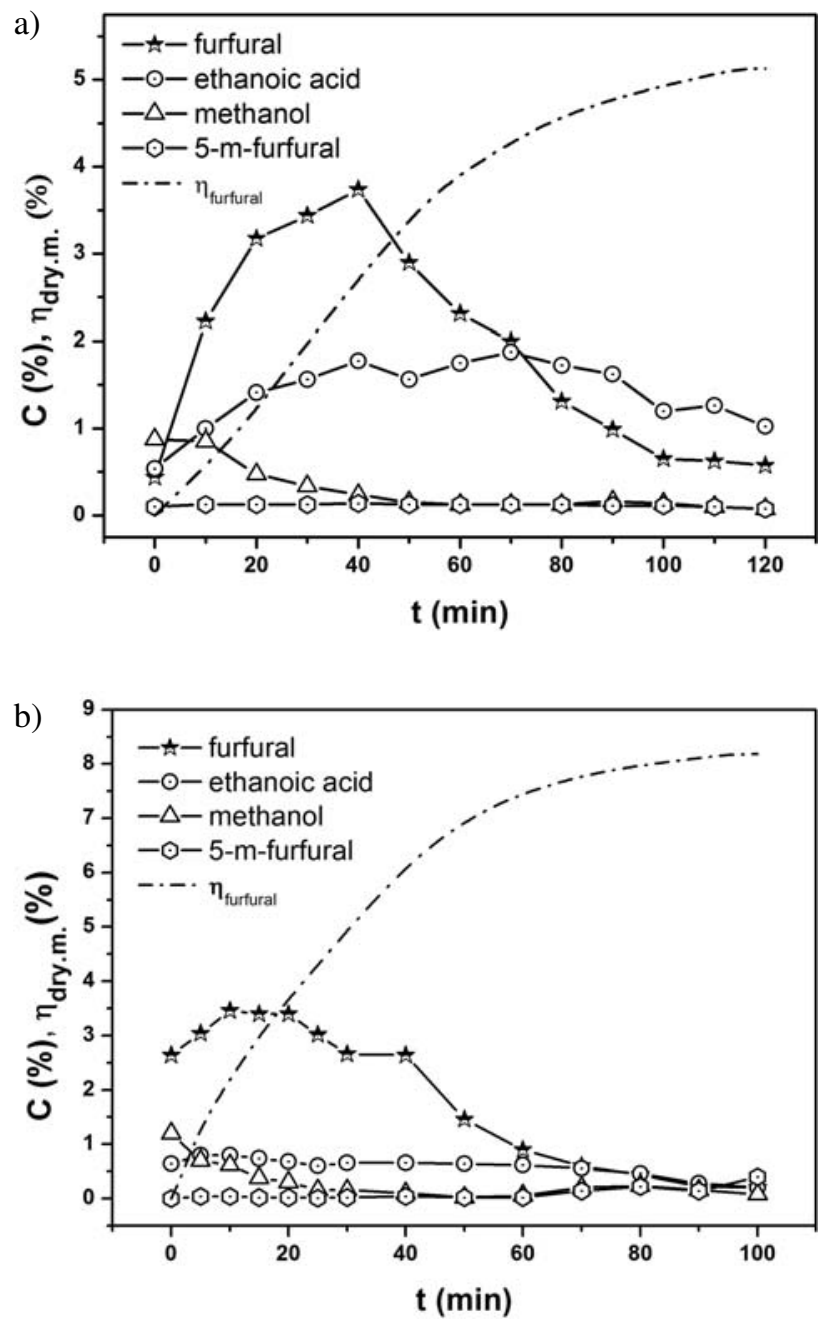

Figure 3. The composition of the outlet flow from the reactor and the furfural yield in a) non-catalysed process (process conditions: $\mathrm{w}_{\mathrm{m}, \mathrm{p}}=31.3 \%, \mathrm{~T}=190{ }^{\circ} \mathrm{C}, \mathrm{P}=11.6$ bar, $\mathrm{S}_{\mathrm{m}}=1.3 \mathrm{~mL} / \mathrm{g} . \mathrm{h}$ ) and $\mathrm{b}$ ) catalysed process by dilute sulphuric acid (process conditions: $\mathrm{w}_{\mathrm{m}, \mathrm{p}}$ $=43.2 \%, \mathrm{w}_{\mathrm{m}, \mathrm{w}}=60 \%, \mathrm{~T}=170{ }^{\circ} \mathrm{C}, \mathrm{P}=6.7 \mathrm{bar}, \mathrm{S}_{\mathrm{m}}=3 \mathrm{~mL} / \mathrm{g} . \mathrm{h}, 0.03$ $\mathrm{g} \mathrm{H}_{2} \mathrm{SO}_{4} / \mathrm{g}$ d.m. using $3.7 \%$ acid concentration).

ule $2 \mathrm{~mL} / \mathrm{g} . \mathrm{h}$ onward, no significant difference in furfural yields between two measured process conditions is observed. By increasing the stripping module from 1.34 to $3.0 \mathrm{~mL} / \mathrm{g} . \mathrm{h}$ at $170{ }^{\circ} \mathrm{C}$ and 7 bar, catalysed by $3.7 \%$ sulphuric acid solution in an amount of $0.03 \mathrm{~g} \mathrm{H}_{2} \mathrm{SO}_{4} / \mathrm{g} \mathrm{d}$.m., an increase of up to $40 \%$ in furfural yield can be gained, which represents around $70 \%$ of theoretically possible furfural yield.

Catalytic experiments were carried out also with higher concentrations of sulphuric acid, namely with $38 \%$ and $90 \%$ solutions. In both cases spraying method was used to apply acid in an amount of $0.038 \mathrm{~g} \mathrm{H}_{2} \mathrm{SO}_{4} / \mathrm{g} \mathrm{d}$.m. The initial moisture content has slightly (around $2 \%$ ) increased when $38 \%$ solution was employed. An issue how to uniformly distribute the acid occurred during application of $90 \%$ sulphuric acid solution due to high viscosity and small amount to be applied. The preheating time had to be shortened to prevent the unwanted side reactions of furfural. The effect of temperature, pressure and stripping module on the
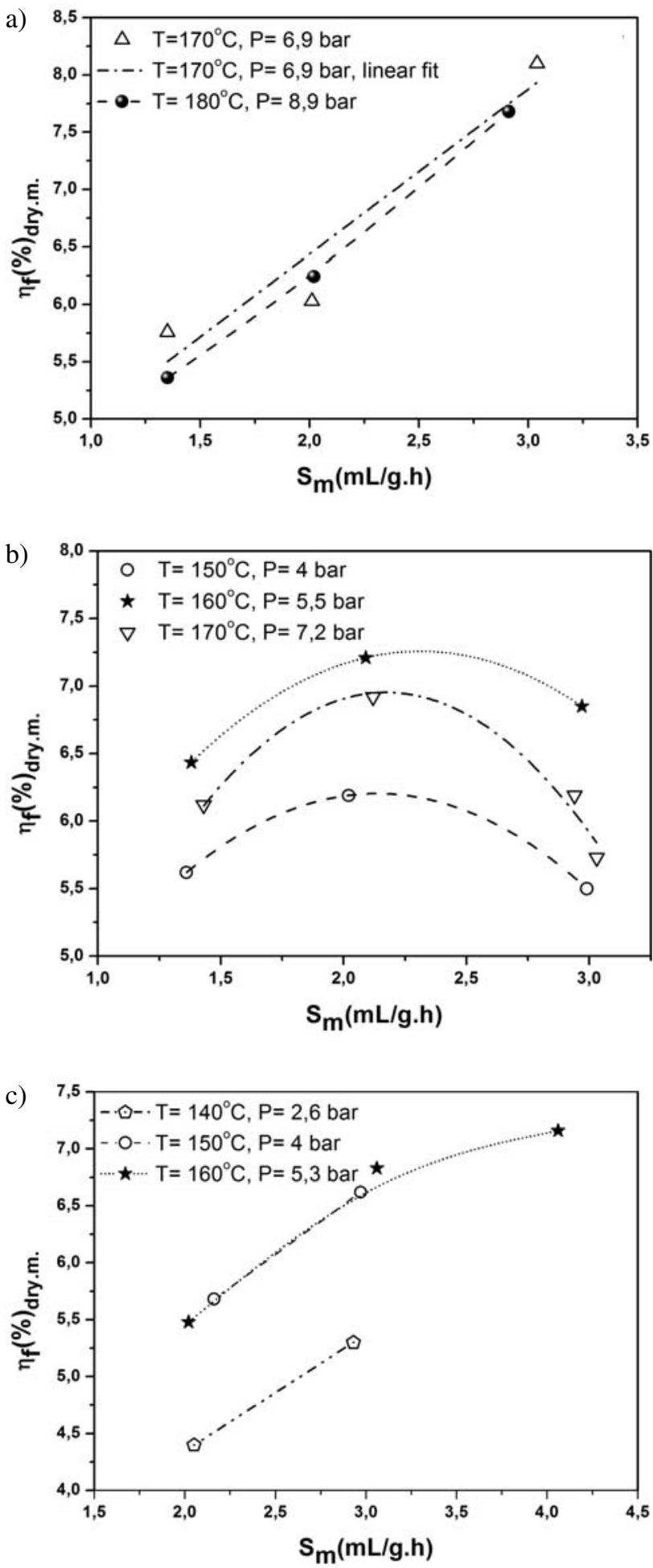

Figure 4. Influence of temperature, pressure and stripping module on furfural yield in catalysed process using a) $3.7 \%$ sulphuric acid solution, b) $38 \%$ solution of sulphuric acid and c) $90 \%$ sulphuric acid solution; the curves are eye guidance. 
furfural yield was studied. Catalysed process with $38 \%$ sulphuric acid has shown best results at $160{ }^{\circ} \mathrm{C}$. Temperature $170^{\circ} \mathrm{C}$ had favorable effect on furfural formation from pentosans, with higher initial and maximal concentrations of furfural observed in the outlet stream from the reactor, but most likely the initial phase of furfural formation was missed; therefore as a result lower furfural yields were obtained. The influence of temperature, pressure and stripping module on furfural yield in the catalysed process by $38 \%$ sulphuric acid solution in the load of $0.038 \mathrm{~g} \mathrm{H}_{2} \mathrm{SO}_{4} / \mathrm{g} \mathrm{d}$.m. is depicted in Figure 4b. It is clearly seen that increasing stripping module resulted in increased furfural yield up to a certain $S_{m}$, and then the drop in furfural yield is noticed, most probably due to condensation of the saturated steam in the reactor and increased liquid film around the particles and therefore increased resistance against the mass transfer to the vapor phase.

In Figure 4c, influence of temperature, pressure and stripping module on furfural yield in the catalysed process by $90 \%$ sulphuric acid solution in a load of $0.037 \mathrm{~g}$ $\mathrm{H}_{2} \mathrm{SO}_{4} / g$ d.m. is presented. Using concentrated sulphuric acid as a catalyst, the formation of furfural was accelerated at lower temperature and pressure, and due to furfural reactivity, side reactions were taking place. One of the reasons for lower furfural yield achieved, compared to lower concentrations of the acid, might also be its nonuniform distribution on wood particles.

Laboratory experiments have shown that sulphuric acid is suitable as a catalyst, in an amount of 0.03-0.04 g $\mathrm{H}_{2} \mathrm{SO}_{4} / g$ d.m., since it enables higher production of furfural at lower temperature and pressure of steam in shorter reaction time, with increased initial, maximal and instantaneous furfural concentrations. The best results were obtained in experimental runs with dilute sulphuric acid at $170{ }^{\circ} \mathrm{C}$ and 7 bar of steam pressure and stripping module of $3 \mathrm{~mL} / \mathrm{g} . \mathrm{h}$. Using the lowest stripping module of 1.35 $\mathrm{mL} / \mathrm{g} . \mathrm{h}$ in catalysed process by dilute sulphuric acid at
$170{ }^{\circ} \mathrm{C}$ (6.9 bar), approximate $12 \%$ higher furfural yield is obtained in comparison with non-catalysed process at 190 ${ }^{\circ} \mathrm{C}$ (11.6 bar).

\section{3. The Effect of Geometry of the Reactor}

Comparison was made between our results obtained on the laboratory scale (NIC), results from research work in Riga (IWC) ${ }^{17}$ and the data from the industrial process (Figure 1), shown in Table 4, with the indication of the geometric characteristic (H/D) of the reactors used for the production of furfural. We refer to the industrial process in Tanin Sevnica chemical company, where the data (per reactor) were obtained from an annual production data of the company (input and output).

From Table 4 it can be seen, that there were big differences in geometry of reactors at NIC, IWC and on industrial site. Geometry of the reactor is one of very important parameters in the process. Decreasing the diameter of the reactor at constant volumetric flowrate of the steam, the Reynolds number for the steam passing through the reactor is increased and therefore the overall mass transfer coefficients from the liquid to the vapor phase are increased in effect. High H/D ratio of the reactor offered two advantages; namely, increased apparent linear velocity of the steam at its constant flowrate and augmented autocatalytic effect in the upper part of the chips bed, caused by released ethanoic acid from the lower part of the reactor. From the comparison of maximal values of linear velocities of the steam calculated on the void cross section of different reactors it can be seen, that linear velocities of steam in experimental runs at NIC were much lower with regard to those at IWC and on industrial site. Therefore, it can be concluded that lower furfural yields were reached in laboratory experiments due to lower linear velocity of the steam and lesser autocatalytic effect caused by the released ethanoic acid.

Table 4. Comparison of operating parameters and results for few non-catalysed and catalysed experiments carried out at NIC, IWC and industrial production data.

\begin{tabular}{|c|c|c|c|c|c|c|c|c|}
\hline \multicolumn{9}{|c|}{ Lab reactor NIC, $\mathrm{H} / \mathrm{D}=2.6$} \\
\hline $\mathbf{m}_{\text {d.m. }} \mathbf{k g}$ & $\mathrm{w}_{\mathrm{m}, \mathrm{p}} \%$ & $\mathrm{C}_{\mathrm{cat}} \%$ & $\mathrm{C}_{\text {d.m. }} \%$ & $\mathbf{T}^{\circ} \mathbf{C}$ & P bar & $S_{m} \mathrm{~mL} / \mathrm{g} \cdot \mathrm{h}$ & $\mathbf{v}_{\text {lin }} \mathbf{m} / \mathbf{s}$ & $\eta_{f} \%$ \\
\hline 0.312 & 43.2 & / & / & 190 & 12 & 1.3 & 0.0020 & 5.1 \\
\hline 0.314 & 42.9 & 3.7 & 3.0 & 170 & 7.0 & 3.0 & 0.0067 & 8.1 \\
\hline 0.314 & 43.0 & 90.0 & 4.3 & 162 & 5.5 & 4.1 & 0.0154 & 7.2 \\
\hline \multicolumn{9}{|c|}{ Lab reactor IWC, H/D = 25.6, superheated steam } \\
\hline 1.427 & 56.5 & l & I & 180 & 9 & 4.0 & 0.0828 & 5.8 \\
\hline 1.440 & 58.5 & 75 & 3 & 160 & 5 & 2.8 & 0.1003 & 7.8 \\
\hline 1.487 & 46.5 & 25 & 3 & 165 & 6 & 2.9 & 0.0871 & 9.4 \\
\hline \multicolumn{9}{|c|}{ Industrial reactor*, $\mathrm{H} / \mathrm{D}=6.2$, superheated steam } \\
\hline$\overline{3400}$ & $42-45$ & / & I & 195 & 9 & 1.3 & 0.1036 & 5.5 \\
\hline
\end{tabular}

$\mathrm{m}_{\mathrm{d} . \mathrm{m} .}-$ mass of dry material, $\mathrm{w}_{\mathrm{m}, \mathrm{p}}-$ average moisture content of material before catalyst application, $\mathrm{C}_{\mathrm{cat}}-\mathrm{concentration}$ of $\mathrm{H}_{2} \mathrm{SO}_{4}$ solution, $\mathrm{C}_{\mathrm{d} . \mathrm{m} \cdot}-{ }^{-}$ an amount of the catalyst on the dry material, $S_{m}-$ stripping module, $v_{\text {lin }}$ - average linear steam velocity, $\eta_{f}-$ furfural yield on the dry basis, ${ }^{*}-$ stage-wise process ( 2 reactors in operation) 


\section{4. Pilot scale Performance}

A series of non-catalysed and catalysed experimental runs were performed systematically on the pilot scale, varying the parameters such as temperature and pressure, the fraction size of the particles used (only in non-catalysed experiments), stripping module, the bed height, the concentration of the catalyst used and the catalyst load. Some results from those experiments are presented in Table 5. maximum yield, between $50 \%$ and $65 \%$, reported by Montane et al. ${ }^{11}$ Using $98 \%$ sulphuric acid, special attention had to be paid to achieve the uniform distribution of the acid on the wood particles.

Pilot scale, non-catalysed and catalysed experiments were both very successful in producing furfural in comparison to laboratory experiments and industrial runs. Furfural yield obtained by non-catalysed process on pilot

Table 5. Operating conditions and results for some non-catalysed and catalysed pilot experiments.

\begin{tabular}{|c|c|c|c|c|c|c|c|}
\hline \multirow[b]{2}{*}{$\mathbf{m}_{\text {d.m. }} \mathbf{k g}$} & \multicolumn{6}{|c|}{ Pilot reactor, $\mathrm{H} / \mathrm{D}=22.5$} & \multirow[b]{2}{*}{$\eta_{\mathrm{f}} \%$} \\
\hline & $\mathbf{w}_{\mathrm{m}, \mathrm{p}} \%$ & $\mathrm{C}_{\mathrm{cat}} \%$ & $\mathrm{C}_{\text {d.m. }} \%$ & $\mathbf{T}^{\circ} \mathbf{C}$ & $\mathbf{P}$ bar & $\mathrm{S}_{\mathrm{m}} \mathrm{mL} / \mathrm{g} . \mathrm{h}$ & \\
\hline 1.891 & 35.2 & 1 & 1 & 189.5 & 12.0 & 0.95 & 5.0 \\
\hline 1.410 & 43.2 & I & I & 190 & 12.0 & 1.67 & 7.1 \\
\hline 1.489 & 50.61 & I & I & 196 & 12.0 & 1.7 & 7.5 \\
\hline 1.505 & 44.53 & 32.1 & 2.2 & 176 & 8.0 & 1.82 & 7.0 \\
\hline 1.553 & 39.60 & 31.2 & 2.1 & 163 & 5.4 & 3.0 & 8.3 \\
\hline 1.410 & 46.75 & 33 & 5 & 166 & 6.0 & 3.99 & 9.9 \\
\hline 1.598 & 48.47 & 98 & 2 & 166 & 5.7 & 2.1 & 8.8 \\
\hline
\end{tabular}

$\mathrm{m}_{\mathrm{d} . \mathrm{m} .}-$ mass of dry material, $\mathrm{w}_{\mathrm{m}, \mathrm{p}}-$ average moisture content of material before catalyst application, $\mathrm{C}_{\text {cat }}-\mathrm{concentration}$ of $\mathrm{H}_{2} \mathrm{SO}_{4}$ solution, $\mathrm{C}_{\mathrm{d} . \mathrm{m} .}-$ an amount of the catalyst on the dry material, $\mathrm{S}_{\mathrm{m}}-$ stripping module, $\eta_{\mathrm{f}}$ - furfural yield on dry basis

It was established that bed, composed of particle fraction size below $1 \mathrm{~mm}$, could drastically (for 50\%) reduce furfural yield compared to the bed composed of particles with size fraction between $6.3 \mathrm{~mm}$ and $11.2 \mathrm{~mm}$. Using different bed heights it was found out that bed height did not have any significant effect on furfural yield, in the dimension studied at one-stage contact. The study on the stripping module at non-catalysed process on nonsieved particles has shown that at low stripping module such as $0.95 \mathrm{~mL} / \mathrm{g}$.h around $30 \%$ lower furfural yield (4.98\%) is achieved compared to stripping module of 1.67 $\mathrm{mL} / \mathrm{g} . \mathrm{h}$ (7.10). Looking at the results of non-catalysed experiments at similar operating conditions on the laboratory scale (Table 2) and on the pilot scale (Table 4), $28 \%$ higher furfural yield is noticed on the pilot scale due to higher linear velocity of the steam achieved and faster furfural removal from the reactor.

In catalysed experiments, sulphuric acid solution of $33 \%$ and $98 \%$ was used as a catalyst in an amount of $0.02-0.05 \mathrm{~g} \mathrm{H}_{2} \mathrm{SO}_{4} / \mathrm{g}$ d.m. The catalyst reduces the activation energy for the reaction of furfural formation, therefore lower temperatures and pressures can be applied. Since the reactions of furfural formation as well as side reactions proceed faster, higher stripping modules are needed to avoid side reactions and furfural losses. The application of $0.05 \mathrm{~g} \mathrm{H}_{2} \mathrm{SO}_{4} / \mathrm{g} \mathrm{d}$ d.m. of $33 \%$ sulphuric acid solution on the particles can give at $166^{\circ} \mathrm{C}$ and 6 bars and high stripping module $(3.99 \mathrm{~mL} / \mathrm{g} . \mathrm{h})$ as high as $9.9 \%$ furfural yield, which corresponds to $88 \%$ of theoretically possible one. The yield is much higher with regard to the scale was $7.1 \%$ on the dry matter at quite low stripping module of $1.67 \mathrm{~mL} / \mathrm{g}_{\text {d.m. }} \mathrm{h}$, which represents $30 \%$ more compared to the yield from industrial stage-wise process and around $61 \%$ of the theoretically attainable. In catalysed experiments up to $40 \%$ to $60 \%$ higher furfural yields under less severe operating conditions (temperature, pressure) can be achieved compared to non-catalysed process.

\section{Conclusions}

Both, laboratory and pilot scale experiments have revealed the most important process parameters that influence the furfural formation, namely temperature, pressure, concentration and amount of the catalyst, furfural removal rate, preheating time, geometry of the reactor and wood particles' fraction size. Higher temperature and pressure increase the furfural production rate in a one-stage noncatalysed process. Higher stripping module related to apparent linear velocity of the steam leads to a rapid removal of furfural (short residence time), thus preventing the undesired side reactions and furfural loss. In a catalysed process, a comparably lower temperature and pressure could be used to achieve even as high as $40-60 \%$ increase in furfural yield compared to a non-catalysed process. Lower pressure enables an enhanced diffusion of the reaction products such as furfural into the bulk steam phase. The pilot scale experiments confirmed the importance of the geometry of the reactor in obtaining the best performance of the furfural production process due to increased 
apparent linear velocity of the steam and augmented autocatalytic effect in the upper part of the chips bed. The experiments have shown the particle fraction size of wood chips had an important impact on the furfural yield, especially when the process was catalysed.

Since the residue after digestion is used to complement the energy requirements of the overall process, the use of sulphuric acid as a catalyst might not be an optimal solution due to the challenges related to the consequent incineration of the processed cellolignin material and other environmental issues $\left(\mathrm{SO}_{3}\right.$ in the exhaust gas). Therefore, other more suitable and more efficient catalysts are required, such as catalysts possessing Lewis/Broensted acid sites to directly impact the dehydration rate and the furfural yield with selectivity towards furfural production.

\section{Acknowledgements}

The research work was financed by ARRS, Slovenian Research Agency (No. 3411-97-22-8693) and Tanin Sevnica chemical company, therefore their financial support is gratefully acknowledged.

\section{Conflict of Interest Statement}

The authors have declared no conflict of interest.

\section{References}

1. Y. Sun, J. Cheng, Bioresour. Technol. 2002, 83, 1-11. http://dx.doi.org/10.1016/S0960-8524(01)00212-7

2. T. Werpy, G. Petersen, Top Value Added Chemicals from Biomass Volume I- Results of the Screening for Potential Candidates from Sugars and Synthesis Gas. NREL/TP-51035523; National Renewable Energy Laboratory (NREL), 2014.

3. H. D. Mansilla, J. Baeza, S. Urzua, G. Maturana, J. Villasenor, N. Duran, Bioresour. Technol. 1998, 66, 189-193.
http://dx.doi.org/10.1016/S0960-8524(98)00088-1

4. N. Vedernikov, New approach in furfural production from pulping waste liquor: Proc. 8th. Intern. Symp. Wood Pulping Chem., Helsinki, Finland, 1995, 367-370.

5. W. Jeaggle, Integrated Production of Furfural and Acetic Acid from Fibrous Residues in a Continuous Process. Escher Wyss News 2, 1975, pp.1-15.

6. N. Abatzoglou, P. G. Koeberle, E. Chornet, R. P. Overend, E. G. Koukios, Can. J. Chem. Eng. 1990, 68, 627-638. http://dx.doi.org/10.1002/cjce.5450680414

7. D. Fengel, G. Wegener, Wood: chemistry, ultrastructure, reactions, Walter de Gruyter \& Co., Berlin, Germany, 1989.

8. A. S. Mamman, J. M. Lee, Y. C. Kim, I. T. Hwang, N. J. Park, Y. K. Hwang, J. S. Chang, J. S., Hwang, Biofuels Bioprod. Biorefin. 2008, 2, 438-454. http://dx.doi.org/10.1002/bbb.95

9. Agirrezabal-Telleria, I. Gandarias, P.L. Arias, Catal. Today 2014, 234, 42-58. http://dx.doi.org/10.1016/j.cattod.2013.11.027

10. M. J. Antal, T. Leesomboon, W. S. Mok, G. N. Richards, Carbohydr. Res. 1991, 217, 71-85. http://dx.doi.org/10.1016/0008-6215(91)84118-X

11. D. Montane, J. Salvado, C. Torras, X. Farriol, Biomass Bioenergy 2002, 22, 295-304. http://dx.doi.org/10.1016/S0961-9534(02)00007-7

12. F. A. Riera, R. Alvarez, J. Coca, J. Chem. Technol. Biotechnol. 1991, 50, 149-155. http://dx.doi.org/10.1002/jctb.280500202

13. V. Choudhary, S. I. Sandler, D. G. Vlachos, ACS Catal. 2012, 2, 2022-2028. http://dx.doi.org/10.1021/cs300265d

14. A. C. Doiseau, F. Rataboul, L. Burel, N. Essayem, Catal. Today 2014, 226, 176-184. http://dx.doi.org/10.1016/j.cattod.2013.10.034

15. N. A. Vedernikov, S. S. Popov, A. Butsene, I. K. Kruma, V. N. Zakharov, D. V. Baldezens, Khim. Drev. 1993, 6, 53-59.

16. M. Nemanič, Študij procesa digestije prešanega izluženca kostanjevega lesa. Diplomsko delo, Fakulteta za kemijo in kemijsko tehnologijo, Univerza v Ljubljani, Ljubljana, 1997.

17. A. Y. Kalninsh, N.A. Vedernikov, Utilization of Harwood as a Chemical Raw Material in Latvian SSR: Appl. Polym. Symp. 1975, 28, 125-130. 


\section{Povzetek}

Predstavljeno delo obravnava vpliv ključnih procesnih spremenljivk na nastanek furfurala pri digestiji prešanega izluženca kostanjevega lesa v tlačnem reaktorju. Sistematično smo študirali vpliv temperature, tlaka, vrste in koncentracije raztopine katalizatorja, pretoka pare oz. »stripping « modula (hitrost odstranjevanja nastalih hlapnih produktov), vsebnosti vlage v lesnih delcih ter vpliv geometrijskih karakteristik kot so oblika in velikost reaktorja, velikost sekancev in višina sloja. Obravnavali smo le enostopenjski proces, eksperimentalno študijo pa smo izvajali v laboratorijskem in pilotnem merilu. Rezultate nekataliziranih laboratorijskih poizkusov smo primerjali z nekataliziranim (avto-kataliziranim) industrijskim procesom in z rezultati eksperimentov, ki so bili izvedeni v pilotnem merilu. V slednjih so bili dobitki furfurala za $28 \%$ višji glede na preostale poizkuse. Uporaba žveplove (VI) kisline kot katalizatorja v nanosu 0,03-0,05 $\mathrm{g} \mathrm{H}_{2} \mathrm{SO}_{4} 100 \% / g$ s.s., omogoča pri nižji temperaturi in tlaku pare doseči večje dobitke furfurala v krajšem reakcijskem času. Katalizirani poizkusi nastanka furfurala v pilotnem merilu so se izkazali kot zelo učinkoviti, saj potekajo pod manj ostrimi pogoji z maksimalnim dobitkom furfurala, ki predstavlja $88 \%$ teoretično možne vrednosti. 